\title{
Soil ploughing for forest regeneration leads to changes in carbon decomposition - a case study with stable isotopes**
}

\author{
Marcin Stróżecki ${ }^{1 *}$, Hanna Silvennoinen ${ }^{2}$, Pawet Strzeliński ${ }^{3}$, and Bogdan Heronim Chojnicki ${ }^{1}$ \\ ${ }^{1}$ Department of Meteorology, Poznań University of Life Sciences, Piątkowska 94, 60-649 Poznań, Poland \\ ${ }^{2}$ NIBIO - Soil and Environment Division, Frederik A. Dahls vei 20 N-1430 Ås, Norway \\ ${ }^{3}$ Department of Forest Management, Poznań University of Life Sciences, Wojska Polskiego 71C, 60-625 Poznań, Poland
}

Received September 5, 2017; accepted February 28, 2018

\begin{abstract}
It is important to quantify carbon decomposition to assess the reforestation impact on the forest floor $\mathrm{C}$ stocks. Estimating the loss of $\mathrm{C}$ stock in a short-term perspective requires measuring changes in soil respiration. This is not trivial due to the contribution of both soil microbes and vegetation to the measured $\mathrm{CO}_{2}$ flux. However, $\mathrm{C}$ stable isotopes can be used to partition the respiration and potentially to assess how much of the recalcitrant $\mathrm{C}$ stock in the forest floor is lost. Here, we measured the soil respiration at two forest sites where different regeneration methods were applied, along with an intact forest soil for reference. In so doing, we used a closed dynamic chamber for measuring respiration and the ${ }^{13} \mathrm{C}$ composition of the emitted $\mathrm{CO}_{2}$. The chamber measurements were then supplemented with the soil organic carbon analysis and its $\delta^{13} \mathrm{C}$ content. The mean $\delta^{13} \mathrm{C}-\mathrm{CO}_{2}$ estimates for the source of the $\mathrm{CO}_{2}$ were $-26.4,-27.9$ and $-29.5 \%$, for the forest, unploughed and ploughed, respectively. The ${ }^{13} \mathrm{C}$ of the soil organic carbon did, not differ significantly between sites. The higher soil respiration rate at the forest, as compared to the unploughed site, could be attributed to the autotrophic respiration by the forest floor vegetation.
\end{abstract}

Keywords: carbon isotope, CRDS, soil respiration

\section{INTRODUCTION}

Forests are among the most important carbon sequestering terrestrial ecosystems. Via photosynthesis, these uptake a large amount of $\mathrm{CO}_{2}$ from the atmosphere and place it in both above and below ground biomass. Approximately, global forests absorb $2.4 \pm 0.8 \mathrm{Gt} \mathrm{C}$ per year (Acosta et al., 2013; Le Quéré et al., 2013; Pan et al., 2011). Forest

*Corresponding author e-mail: marcin.strozecki@gmail.com **This work was co-founded by the Polish National Centre for Research and Development within the Polish-Norwegian Research Programme within the WETMAN (Central European Wetland Ecosystem Feedbacks to Changing Climate - Field Scale Manipulation, Project ID: 203258, contract No. Pol-Nor/ 203258/31/2013) project. floor $\mathrm{C}$ stock is highly variable and depends on tree species, i.e. beech, larch, or oak: $11.1,29.6$, or $24.62 \mathrm{Mg} \mathrm{C}$ $\mathrm{ha}^{-1}$ year, respectively. Moreover, it varies geographically (Schulp et al., 2008; Thuille and Schulze, 2006). The $\mathrm{CO}_{2}$ exchange between the atmosphere and the soil is an important part of the C cycle (Ussiri and Lal, 2009) and soil respiration is a primary mechanism of an ecosystem carbon (C) loss. Such loss results from the metabolism of microbes, microflora and fauna. It is, therefore, affected by practices like tillage and residue management (Jandl et al., 2007).

Carbon stored in terrestrial ecosystems is usually more depleted in the heavy isotope $\left({ }^{13} \mathrm{C}\right)$ than in atmospheric carbon, due to fractionation (preferential uptake of the lighter isotope) of rubisco and PEP-c in photosynthesis (Affek and Yakir, 2014; Bowling et al., 2008; Damesin and Lelarge, 2003; O’Leary, 1993; van Asperen et al., 2017; Vogel; 1993; Yakir, 2003). The ${ }^{13} \mathrm{C}$ signatures of the atmosphere and vegetation vary in time and space, and depend on geographical location (Bowling et al., 2015; Brugonli and Farquhar, 2000; Ghashghaie, 2003; Liang et al. 2016). While part of the ${ }^{13} \mathrm{C}$ - depleted litter created from the plants decomposes over time, as the lighter $\mathrm{C}$ isotope $\left({ }^{12} \mathrm{C}\right)$ is preferentially consumed, the remaining SOC is eventually enriched with ${ }^{13} \mathrm{C}$ (Menichetti et al., 2014; Persson, 2000).

$\mathrm{CO}_{2}$ is produced in the respiration of plant stems and roots (autotrophic respiration), and in the respiration of microbes and micro fauna (heterotrophic respiration) (Schulze, 2000). As plants are the main sources of $\mathrm{C}$ for most types of soils, the amount of SOC and its isotopic

(C) 2018 Institute of Agrophysics, Polish Academy of Sciences 
composition depend on the flora in a given ecosystem. Roots also supply soil with $\mathrm{C}$ (via root exudates) which has an isotopic signature similar to that found in plants $\left(\delta^{13} \mathrm{C}\right)$. These biogeochemically-driven shifts in the ${ }^{13} \mathrm{C}$ composition facilitate the use of stable isotope in detailed process studies, but this requires further investigations under field conditions. Due to technological advances, high frequency stable isotope measurements have become both technically and financially feasible in situ (Bahn et al., 2009; Liang et al., 2016; Snell et al., 2014). For that reason, the $\delta^{13} \mathrm{C}$ abundance approach was applied in our work, in order to test its reliability on assessing the forest management impact on changes in forest floor carbon decomposition.

Dynamic closed chambers have been widely used to assess gas exchange between the atmosphere and the analyzed surface (Chojnicki et al., 2008; Görres et al., 2016). This technique is mainly used in measuring fluxes of $\mathrm{CH}_{4}$, $\mathrm{CO}_{2}$ and $\mathrm{N}_{2} \mathrm{O}$ when high spatial variability prevents the use of the Eddy Covariance method (Juszczak, 2013). In our study, we combined a dynamic chamber with a cavity ring down spectrometer which measures both $\mathrm{CO}_{2}$ concentration and its ${ }^{13} \mathrm{C}$ signature so as to determine source estimates for the respired $\mathrm{CO}_{2}$. In addition, the ${ }^{13} \mathrm{C}$ signature of the source of soil respiration was determined with a commonly used method, based on the mass conservation law (Keeling 1958, 1961; Pataki et al., 2003).

Variable soil preparation methods used in Polish forestry include ploughing (furrows), rotary tilling (bare soil belts) and scarifying the surface, along with handmade bare soil grids and mounds, as well as beds and roll (Jakubowski et al., 2013). Sparsely vegetation-covered clear cuts are commonly machine-ploughed to bare soil belts and furrows, whereas manual methods are used to create shallow furrows, bare soil grids or even mounds in densely vegetation-covered areas. These reforestation methods are not used in wet locations when the natural tree coverage regeneration is possible (The guide of forest management, 2012). All the above described methods disturb the soil structure and may enhance soil respiration (Johnson and Curtis, 2001). The spatial scale of such disturbances differs between various preparation techniques. The furrows and bare soil belts introduce more spatial destruction than bare soil grids but they are easier to implement with machines.

Forest soil is commonly ploughed in Poland when preparing soil for forest regeneration. However, there are few methods that allow measuring the impact of soil preparation on soil $\mathrm{C}$ stocks on a short term. Thus, the aim of this study was to test the following hypotheses:

- the natural abundance of $\mathrm{C}$ stable isotopes can be used to differentiate sources of soil respiration at forest soils under various forest regeneration methods since they yield different $\delta^{13} \mathrm{C}-\mathrm{CO}_{2}$ in the respired $\mathrm{CO}_{2}$,

- and the $\delta^{13} \mathrm{C}-\mathrm{CO}_{2}$ signature of a ploughed site differs from that of a forest or an unploughed site.

\section{METHODS}

The study area was situated $1.5 \mathrm{~km}$ from the town of Tleń, Poland (53.63N 18.25E). The topography of the area covering the forest division is characterized by postglacial outwash plains and rusty soils with podzolic brown soils subtype. The chosen site was located in the transition zone of the temperate climate between the continental and oceanic zones. The dominant species was Scots pine (Pinus sylvestris L.) at $95.6 \%$, with a slight admixture of Silver birch (Betula pendula Roth), Norway spruce (Picea abies L.) H. Karst) and English oak (Quercus robur L.). The mean age of the stand at district is 72 years (Forest, 2007) - which is similar to the national forest average (60 years).

The average annual air temperature in this area is $7.0^{\circ} \mathrm{C}$, while the average temperature of the coldest month (January) is $-2.4^{\circ} \mathrm{C}$, and that of the warmest month (July) is $+18^{\circ} \mathrm{C}$ (Forest, 2007). The 30 years average annual precipitation total in the region is $548 \mathrm{~mm}$, which is lower than the average value for Poland $(622.8 \mathrm{~mm})$ by almost $80 \mathrm{~mm}$ (Lorenc, 2005).

In the study area, on July 12, 2012, a tornado, destroyed 470 ha of pine forest aged 80 years. After timber removal, the area was prepared for regeneration by means of two variants. The first variant was ploughing by doublemould-board plough (the furrows). Herein, the topsoil was partly turned up completely covering the previous vegetation. Furthermore, before tillage, all the stumps were mechanically removed. In the second variant, tree residues, including stumps, were left on site and manual regeneration plantings was done on the previously prepared bare soil grids where the upper organic soil horizon had been removed.

For the purpose of the experiment in question, three sites were established. The first one, denoted as 'Ploughed' was at the ploughed site. Due to the lack of SOC in the ridges, the soil collars were situated on the top of the furrows so as to estimate emission from disturbed and $\mathrm{C}$ containing soil layers. The second experimental site was established in the site where no tillage was performed and was denoted as 'Unploughed'. This site was covered with poorly developed vegetation, with wavy hair-grass (Deschampsia flexuosa L.) as the dominant species. The third site was situated in the nearby forest which was unaffected by the tornado, and was denoted as 'Forest'. This last experimental site was covered with well-developed vegetation, comprising such plants as bilberry (Vaccinium myrtillus L.), lingonberry (Vaccinium vitis-idaea L.), as well as mosses, e.g. haircap moss (Polytrichum sp.) and red-stemmed feather moss (Pleurozium schreberi (Willd.) Mitten.). At each measuring site, three collars were installed (random location).

Measurements on $\delta^{13} \mathrm{C}$ content emitted from soil respiration were carried out October 21, 2014 using a dynamic closed chamber method. The closed chamber $(77 \times 77$ x $50 \mathrm{~cm}$ ) was made of opaque polyvinyl chloride, and in 
order to ensure the adequate air mixing in the headspace, the chamber was equipped with three $(12 \mathrm{~V}, 1.2 \mathrm{~W})$ fans at an angle of $45^{\circ}$. The headspace was analyzed using a dual $\left(\mathrm{CO}_{2} / \mathrm{CH}_{4}\right) \mathrm{G} 2201-i$ isotopic cavity ring down spectrometer (CRDS) coupled with a closed air circuit (chamber-analyzer) via an additional air pump $\left(101 \mathrm{~min}^{-1}\right)$ that reduced the response time. The chamber was placed over a pre-installed $(24 \mathrm{~h})$ collar $(75 \times 75 \times 20 \mathrm{~cm})$. Measurements were carried out until the headspace $\mathrm{CO}_{2}$ concentration reached 660 ppm (mean enclosure time approx. $35 \mathrm{~min}$ ) and the ambient carbon dioxide concentration was approx. 398 ppm. Each study site (with three replicates) was measured only once.

As the recently assimilated ${ }^{13} \mathrm{C}$ depleted carbon remains mobile in plants for as long as $24 \mathrm{~h}$ after assimilation (Bahn, 2013; Farquhar et al., 1989), we covered the plots with an opaque material one day before the analysis. Thus, the $\mathrm{CO}_{2}$ emitted from the soil was not recently assimilated $\mathrm{C}$, but it was produced from the SOC decomposition which carried a legacy of the $\mathrm{C}$ photosynthesized just before covering the plot. To estimate the $\delta^{13} \mathrm{C}$ of the source of respiratory $\mathrm{CO}_{2}$, we used a Keeling plot approach. This method assumes that the background air has a constant $\mathrm{CO}_{2}$ isotopic composition and concentration. The $\delta^{13} \mathrm{C}$ was plotted as a function of the reciprocal of the measured gas concentrations (1/ $\mathrm{CO}_{2}$ ), while the y-intercept denoted the $\delta^{13} \mathrm{C}$ of the source for respiration.

Soil samples (3 samples after each chamber measurement) were collected from a depth of 2-10 cm below the soil surface of each collar. In the ploughed site, SOM samples were taken only from the ridges, since the mineral material in the furrows did not contain organic matter.

Table 1. Meteorological characteristics of the Tlen forest (September 16 to October 21, 2014)

\begin{tabular}{cccccc}
\hline $\begin{array}{c}\mathrm{Rs} \\
\left(\mu \mathrm{mol} \mathrm{m} \mathrm{m}^{-2}\right)\end{array}$ & $\begin{array}{c}\mathrm{Ta} \\
\left({ }^{\circ} \mathrm{C}\right)\end{array}$ & $\begin{array}{c}\mathrm{RH} \\
(\%)\end{array}$ & $\begin{array}{c}\mathrm{Ts} \\
\left({ }^{\circ} \mathrm{C}\right)\end{array}$ & $\begin{array}{c}\mathrm{SM} \\
(\%)\end{array}$ & $\begin{array}{c}\mathrm{P} \\
(\mathrm{mm})\end{array}$ \\
\hline 195.45 & 11.22 & 82,78 & 12.58 & 4.9 & 63.15 \\
$(70.0)$ & $(10.75)$ & $(89.5)$ & $(11.70)$ & $(5.9)$ & $(2.25)$ \\
\hline
\end{tabular}

Rs - average global radiation, $\mathrm{Ta}$ - air temperature, $\mathrm{RH}$ - relative humidity, Ts - soil temperature, SM - soil moisture and P - total precipitation. Values in parentheses are average values from the day preceding the measurements.
Samples were dried $\left(72 \mathrm{~h}, 60^{\circ} \mathrm{C}\right)$, ground and measured for $\delta^{13} \mathrm{C}$ with a CRDS (Picarro G1121-i) equipped with a dry combustion module.

Soil respiration was calculated on the basis of the concentrations changes (the linear approach) that were obtained via Picarro analyzer. The same methodology was applied for both total $\mathrm{CO}_{2}$ and ${ }^{13} \mathrm{C}_{-} \mathrm{CO}_{2}$ emission estimations.

All the statistical analyses were made using $\mathrm{R}^{\odot}$ software (ver. x64 2.15.2).

\section{RESULTS}

Weather conditions were monitored from the moment of ploughing to the respiration measurements. Air temperature (Ta) and relative humidity $(\mathrm{RH})$ measurements were taken at $200 \mathrm{~cm}$ above the ground level, whereas precipitation (P), solar radiation (Rs) and the soil temperature were obtained at a depth of $5 \mathrm{~cm}$ (Ts). Finally, soil moisture was analyzed at a depth of $5 \mathrm{~cm}(\mathrm{SM})$ (Table 1).

The forest site and the unploughed site had lower $\delta^{13} \mathrm{C}_{-} \mathrm{CO}_{2}{ }^{\text {resp }}$ (-29.53 and $-27.98 \%$, respectively), while the ploughed site exhibited the highest signature $(-26.49 \%)$. The ${ }^{13} \mathrm{C}$ signatures of SOC were $-28.92,-28.32$ and $-28.13 \%$ for the 'Ploughed', 'Unploughed' and 'Forest' sites (Table 2).

The normal distribution of the collected data was analysed by means of the Shapiro-Wilk test. Significant differences in variances were not found for either of the analyzed cases, i.e. $\delta^{13} \mathrm{C}-\mathrm{CO}_{2}{ }^{\text {resp }}$ and $\delta^{13} \mathrm{C}-\mathrm{CO}_{2}{ }^{\text {soc }}$ (the Fisher test). For that reason, Student's t-test was then applied to determine the similarity of the analyzed samples. Our results show that there are significant differences between pairwise comparisons for air samples $-\delta^{13} \mathrm{C}_{-} \mathrm{CO}_{2}{ }^{\text {resp }}$ (Fig. 1A). However, we did not find any differences between the pairs of collected SOC samples $-\delta^{13} \mathrm{C}_{-} \mathrm{CO}_{2}^{\text {soc }}$ (Fig. 1B). The difference in soil respiration was significant only between ploughed and unploughed sites (Fig. 1C).

\section{DISCUSSION}

The highest Keeling plot intercepts were recorded at the ploughed site $(-26.49 \%)$, most likely due to the physical disturbance. The most complex, and therefore recalcitrant, structures of the SOM are often found to be the most ${ }^{13} \mathrm{C}$ enriched (Menichetti et al., 2014). It is striking that not

Table 2. Keeling plot intercepts of respired $\mathrm{CO}_{2}\left(\delta^{13} \mathrm{C}_{-} \mathrm{CO}_{2}{ }^{\text {resp }}, \mathrm{n}=3\right)$, isotopic signatures for $\mathrm{CO}_{2}$ in $\mathrm{SOC}_{\text {samples }}\left(\delta^{13} \mathrm{C}-\mathrm{CO}_{2}{ }^{\text {soc }}\right.$, $\mathrm{n}=9)$ and average soil respiration $(\mathrm{n}=3)$

\begin{tabular}{lcccccccc}
\hline Site & $\delta^{13} \mathrm{C}^{-\mathrm{CO}_{2}{ }^{\text {resp }}}$ & $\sigma$ & $\delta^{13} \mathrm{C}^{-\mathrm{CO}_{2}{ }^{\text {soc }}}$ & $\Sigma$ & $\begin{array}{c}\text { Flux } \\
\mathrm{C}^{-\mathrm{CO}_{2}} \\
\left(\mathrm{~g} \mathrm{~m}^{2} \mathrm{~h}^{-1}\right)\end{array}$ & $\sigma$ & $\begin{array}{c}\text { Flux } \\
{ }^{13} \mathrm{C}_{-1 \mathrm{CO}_{2}} \\
\left(\mathrm{mg} \mathrm{m}^{2} \mathrm{~h}^{-1}\right)\end{array}$ & $\sigma$ \\
\hline Ploughed & -26.49 & 0.39 & -28.92 & 0.88 & 0.19 & 0.03 & 0.08 & 0.040 \\
Unploughed & -27.98 & 0.46 & -28.40 & 0.77 & 0.11 & 0.005 & 0.04 & 0.003 \\
Forest & -29.75 & 0.38 & -28.13 & 0.70 & 0.14 & 0.010 & 0.05 & 0.001 \\
\hline
\end{tabular}



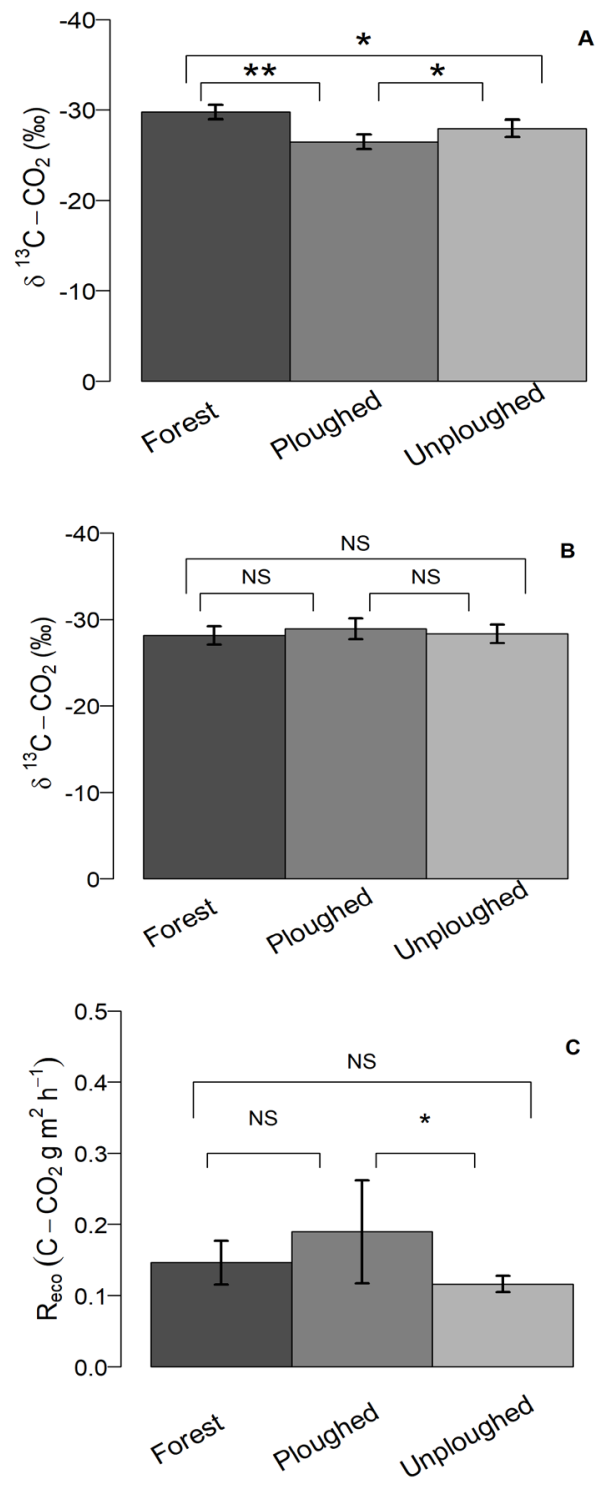

Fig. 1. The $\delta^{13} \mathrm{C}-\mathrm{CO}_{2}$ values in the emitted air (A), in SOM (B) and ecosystem respiration of $\mathrm{C}-\mathrm{CO}_{2}(\mathrm{C})$ at individual experimental sites and levels of significance, where: ${ }^{*} \mathrm{p} \leq 0.05 ; * * \mathrm{p} \leq 0.001$; $\mathrm{NS}-\mathrm{p}>0.05$.

only the Keeling plot intercept was significantly highest at the ploughed site, but also the respiration rate (Fig. 1C). Two of the most important factors which have impact on the $\mathrm{C}-\mathrm{CO}_{2}$ flux are soil moisture and temperature. Still, in our case, the impact of these factors was negligible since the soil temperature observed during the chamber measurements varied within the range of $0.9^{\circ} \mathrm{C}$ during the whole measuring period. However, soil moisture recorded on each site was equal to $4.9 \pm 0.1 \%$. As compared to the ploughed site, the unploughed and the forest sites exhibited lower values for the source estimate. The aforementioned values indicate that the $\mathrm{CO}_{2}$ emitted from these sites contained more ${ }^{12} \mathrm{C}$. This results from the depleted ${ }^{13} \mathrm{C}$ - signature of the decomposing material. ${ }^{13} \mathrm{C}$ depleted 'fresh' $\mathrm{SOC}$ is less decomposed than SOC that is enriched with ${ }^{13} \mathrm{C}$, i.e. the ${ }^{13} \mathrm{C}$ depleted material contains more $\mathrm{C}$ from recent assimilates. Based on these results, the presence of living (photo-synthetically active) plants renders the $\delta^{13} \mathrm{C}$ signature of the $\mathrm{CO}_{2}$ source estimate more negative, as compared to that of the plant-free site (Fig. 1A). These results correspond to information presented in other literature sources. For instance, Ekbald and Högberg (2001) reported that soil respiration from a boreal forest showed large seasonal variation in natural abundance of ${ }^{13} \mathrm{C}$ (from -21.6 to $-26.5 \%$ ).

We hypothesize that plant coverage at the measurement sites determined the $\delta^{13} \mathrm{C}$ signature value. Our results show that the most ${ }^{13} \mathrm{C}$ depleted $\mathrm{CO}_{2}$ source estimates were recorded for the forest site where a dense plant cover and adjacent trees provided an ample supply of recently assimilated, ${ }^{13} \mathrm{C}$ depleted carbon (Fig. 1A). Moreover, at the ploughed site, the lack of recently assimilated, labile $\mathrm{C}$, provided by plants may enhance the usage of previously stored $\mathrm{SOC}$ (with a more enriched ${ }^{13} \mathrm{C}$ signature). Simultaneously, the SOC stock has faced physical disturbance and exposure to oxygen, hence, making it readily decomposable.

The ${ }^{13} \mathrm{C}$-signature of the soil samples $\left({ }^{13} \mathrm{C}^{-} \mathrm{CO}_{2}{ }^{\mathrm{soc}}\right) \mathrm{did}$ not differ significantly between sites, while differences in the ${ }^{13} \mathrm{C}$-signature of the source estimate of $\mathrm{CO}_{2}$ were significant. At the ploughed site, the mineral layer (the ridge) covered the upper organic layer, including the vegetation cover, after ploughing. The ridge may have isolated the layer with dead plants so that the depleted $\mathrm{CO}_{2}$ fraction originated from decomposition of those plants was not emitted. Therefore, the more enriched ${ }^{13} \mathrm{C}$ signature was most likely caused by the decomposition of the recalcitrant SOC.

The annual variations in $\mathrm{CO}_{2}$ fluxes from temperate forest soils are said to range from 0 to $3.60 \mathrm{~g} \mathrm{~m}^{2} \mathrm{~h}^{-1}$ (Wang et al., 2009; Xu and Qi, 2001). In our case, the measured fluxes were in the lower state $\left(0.11-0.23 \mathrm{~g} \mathrm{~m}^{2} \mathrm{~h}^{-1}\right)$ of this range. This situation is most likely due to physical disturbances and to mixing the mineral layer with the SOM f, facilitating better oxygen diffusion, as the respiration at the ploughed site was $31 \%$ and $64 \%$ higher than at forest and unploughed sites, respectively (Fig. 1C). This leads to the conclusion that in the ridges, organic matter and mineral soil were mixed - resulting in optimal conditions for decomposing organisms. (Davidson et al., 1998; Edwards, 1975; Pumpanen 2004; Salonius, 1983). Beyond the aforementioned, a mechanical soil structure modification increases $\mathrm{R}_{\text {eco }}$ more efficiently than the presence of plant covers. Higher $\mathrm{CO}_{2}$ emission in the forest, as compared to the unploughed site (statistically insignificant), also leads to the conclusion that increased $\mathrm{R}_{\text {eco }}$ results from the presence of a denser vegetation's cover and a live root biomass. Such a situation results in an increase in the autotrophic part of soil respiration.

The combination of the $\mathrm{CO}_{2}$ flux chamber method and the $\delta^{13} \mathrm{C}$ CRDS abundance technique provides an insight into the impact of the tillage process on the forest soil $\mathrm{C}$ 
stock decomposition. The obtained results show that forest regeneration without ploughing had the lowest respiration and the highest $\delta^{13} \mathrm{C}$ signature. This may potentially indicate an increased loss of recalcitrant SOC than in the other soil preparation methods.

Having regard to the fact that the $\delta^{13} \mathrm{C}_{-} \mathrm{CO}_{2}$ measurements were made only on one day, the obtained result cannot be generalized and transferred to the entire forest ecosystem. With this experiment, we wanted to prove the great potential of the applied methodology. We, therefore, encourage further research on the topic, with a view to verifying and quantifying the losses, as well as facilitating forest management practices that are both socio-economically feasible and climatically beneficial.

\section{CONCLUSIONS}

Consistent initial predictions, each type of the forest regeneration methods leads to different ${ }^{13} \mathrm{C}-\mathrm{CO}_{2}$ outcomes from soil. This study was conducted as a first attempt to assess the potential of natural abundances ${ }^{13} \mathrm{C}$ in estimating forest management driven soil C losses. At this stage of our research, we can conclude that:

1. The highest value of $\delta^{13} \mathrm{C}-\mathrm{CO}_{2}$ was noticed at the ploughed site. This may indicate that disturbances in the forest soil structure induced by ploughing lead to increased soil microbial activity and the activation of pre-absorbed carbon in the form of ${ }^{13} \mathrm{C}$ isotope.

2. Any significant differences in isotope content in SOM was recorded. Therefore, the regeneration method does not affect the ${ }^{13} \mathrm{C}$ isotope content in soil.

3. The significant difference (lowest value of $\delta^{13} \mathrm{C}^{-} \mathrm{CO}_{2}$ in emitted air) between forest and other sites is the result of the presence of the denser vegetative cover and live root biomass that results in an increase in the autotrophic part of soil respiration.

Conflict of interest: The Authors do not declare conflict of interest.

\section{REFERENCES}

Acosta M., Pavelka M., Tomaškova I., Montagnani L., Kutsch W., Lindroth A., Juszczak R., and Janouš D., 2013. Soil surface $\mathrm{CO}_{2}$ efflux measurements In Norway spruce Forests: Comparison between four sites across Europe from boreal to Alpine forest. Geoderma, 192, 295-303.

Affek H.P. and Yakir D., 2014. The stable isotopic composition of atmospheric $\mathrm{CO}_{2}$. Elsevier Ltd.

Bahn M., Lattanzi F. A., Hasibeder R., Wild B., Koranda M., Danese V., Brüggemann N., Schmitt M., Siegwolf R., and Richter A., 2013. Responses of belowground carbon allocation dynamics to extended shading in mountain grassland. New Phytologist, 198, 116-126.

Bahn M., Schmitt M., Siegwolf R., Richter A., and Brüggemann N., 2009. Does photosynthesis affect grassland soil-respired $\mathrm{CO}_{2}$ and its carbon isotope composition on a diurnal timescale? New Phytologist, 182(2), 451-60.
Bowling D., Egan J., Hall S., and Risk D., 2015. Environmental forcing does not induce diel or synoptic variation in the carbon isotope content of forest soil respiration. Biogeosciences, 12, 5143-5160.

Bowling D.R., Pataki D.E., and Randerson J.T., 2008. Carbon isotopes in terrestrial ecosystem pools and $\mathrm{CO}_{2}$ fluxes. New Phytologist, 178(1), 24-40.

Brugonli E. and Farquhar G.D., 2000. Photosynthetic fractionation of carbon isotopes. Physiology and Metabolism, 399-434.

Chojnicki B.H., Urbaniak M., Leśny J., Juszczak R., and Olejnik J., 2008. Modern methods to measure mass and energy exchanges between the soil and the atmosphere (in Polish). Przegląd Naukowy - Inżynieria i Kształtowanie Środowiska, 39, 91-97.

Damesin C. and Lelarge C., 2003. Carbon isotope composition of current-year shoots from Fagus sylvatica in relation to growth, respiration and use of reserves. Plant Cell Environ., 26, 207-219.

Davidson E.A., Belk E., and Boone R.D., 1998. Soil water content and temperature as independent or confounded factors controlling soil respiration in a temperate mixed hardwood forest. Global Change Biol., 4, 217-227.

Edwards N.T., 1975. Effects of temperature and moisture on carbon dioxide evolution in a mixed deciduous forest floor. Soil Sci. Soc. Am. Proc., 39, 361-365.

Ekbald A. and Högberg P., 2001. Natural abundance of ${ }^{13} \mathrm{C}$ in $\mathrm{CO}_{2}$ respired from forest soils reveals speed of link between tree photosynthesis and root respiration. Oecologia, 127, 305-308.

Farquhar G.D., Ehleringer J.R., and Hubick K.T., 1989. Carbon isotope discrimination and photosynthesis. Annual Rev. Plant Physiology, 40, 503-537.

Forest management plan for the Trzebciny Forest Division for the period 01.01.2007 - 31.12.2016 (in Polish). Bureau for Forest Management and Geodesy, Gdynia, Poland.

Ghashghaie J., Badeck F.W., Lanigan G., Nogues S., Tcherkez Deleens E., Cornic G., and Griffiths H., 2003. Carbon isotope fractionation during dark respiration and photorespiration in $\mathrm{C}_{3}$ plants; Phytochemistry Reviews, 2, 145-161.

Görres C.M., Kammann C., and Ceulemans R., 2016. Automation of soil flux chamber measurements: potentials and pitfalls. Biogeosciences, 13, 1949-1966.

Jakubowski J., Gornowicz R., Pilarek Z., and Kiedrowski T., 2013. The influence of cutting residues management and soil preparation methods on height of 3-year-old Scots pine (Pinus sylvestris L.) plantation. Acta Sci. Pol., Silv. Colendar. Rat. Ind. Lignar., 12(4), 33-41.

Jandl R., Lindner M., Vesterdal L., Bauwens B., Baritz R., Hagedorn P., Johnson D.W., Minkkinen K., and Byrne K.A., 2007. How strongly can forest management influence soil carbon sequestration. Geoderma, 137, 253-268.

Johnson D.W. and Curtis P.S., 2001. Effects of forest management on soil $\mathrm{C}$ and $\mathrm{N}$ storage: meta analysis. Forest Ecology and Manag., 140, 227-238.

Juszczak R. and Augustin J., 2013. Exchange of the greenhouse gases methane and nitrous oxide at a temperate pristine fen mire in Central Europe. Wetlands, 33(5), 895-907. 
Keeling C.D., 1958. The concentration and isotopic abundances of atmospheric carbon dioxide in rural areas. Geochimica et Cosmochimica Acta, 13, 322-334.

Keeling C.D., 1961. The concentration and isotopic abundance of carbon dioxide in rural and marine air. Geochimica et Cosmochimica Acta, 24, 277-298.

Le Quéré C., Andres R.J., Boden T., Conway T., Houghton R.A., House J.I., Marland G., Peters G.P., van der Werf G.R., Ahlström A., Andrew R.M., Bopp L., Canadell J.G., Ciais P., Doney S.C., Enright C., Friedlingstein P., Huntingford C., Jain A.K., Jourdain C., Kato E., Keeling R.F., Klein Goldewijk K., Levis S., Levy P., Lomas M., Poulter B., Raupach M.R., Schwinger J., Sitch S., Stocker B.D., Viovy N., Zaehle S., and Zeng N., 2013. The global carbon budget 1959-2011. Earth System Science Data, 5, 1107-1157.

Liang L.L., Riveros-Iregui D.A., Risk D.A., 2016. Spatial and seasonal variabilities of the stable carbon isotope composition of soil $\mathrm{CO}_{2}$ concentration and flux in complex terrain. J. Geophysical Res., Biogeosienes, 121, 2328-2339.

Lorenc H., 2005. Atlas of climate of Poland (in Polish). Institute of Meteorology and Water Management, Warsaw, Poland.

Menichetti L., Houout S., van Oort F., Katterer T., Christensen B.T., Chenu C., Barre P., Vasilyeva N.A., and Ekbald A., 2014. Increase in soil stable carbon isotope ratio relates to loss of organic carbon; results from five-term bare fallow experiments. Oecologia, 177(3), 811-821, doi: 10.1007/ s00442-014-3114-4

O'Leary M.H., 1993. Biochemical basis of carbon isotope fractionation. Stable Isotopes and Plant CarbonWater Relations, 19-28.

Pan Y., Birdsey R.A., Fang J., Houghton R., Kauppi P.E., Kurz W.A., Phillips O.L., Shvidenko A., Lewis S.L., Canadell J.G., Ciais P., Jackson R.B., Pacala S.W., McGuire D., Piao S., Rautiainen A., Sitch S., and Hayes D., 2011. A large and persistent carbon sink in the world's forests. Science, 333, 988-993.

Pataki D.E., Eheringer J.R., Flanagan L.B., Yakir D., Bowling D.R., Still C.J., Buchmann N., Kapan J.O., and Berry J.A., 2003. The application and interpretation of Keeling plots in terrestrial carbon cycle research. Global Biogeochemical Cycles, 17(1), 1022, doi:10.1029/2001GB001850, 22-1-22-14.

Persson T., Karlsson PS., Seyferth U., Sjöberg R.M., and Rudebeck A., 2000. Carbon mineralization in European forest soils. Ecological Studies, 142, 257-275.
Pumpanen J., Westman C.J., and Ilvesniemi H., 2004. Soil $\mathrm{CO}_{2}$ efflux from a podzolic forest soil before and after forest clear-cutting and site preparation. Boreal Environment Res., 9, 199-212.

Salonius P.O., 1983. Effects of organic-mineral soil mixtures and increasing temperature on the respiration of coniferous raw humus material. Can. J. For. Res., 13, 102-107.

Schulp J.E.C., Nabuurs G.J., Verburg P.H., and de Waal R.W., 2008. Effect of tree species on carbon stocks in forest floor and mineral soil and implications for soil carbon inventories. Forest Ecology Manag., 256, 482-490.

Schulze E.-D., 2000. The carbon and nitrogen cycles of forest ecosystems in Carbon and Nitrogen Cycling in European Forest Ecosystems (Ed.), Ecological Studies, SpringerVerlag, Berlin, Heidelberg, New York ISBN 3-540-67025-4 :3-11.

Snell H.K., Robinson D., and Midwood A.J., 2014. Minimizing methodological biases to improve the accuracy of portioning soil respiration using natural abundance ${ }^{13} \mathrm{C}$. Rapid Communication in Mass Spectrometry, 28, 2341-2351.

The guide of forest management, 2012. Ed. M. Haze, Clip, Warszawa, Poland.

Thuille A. and Schulze E.D., 2006. Carbon dynamics in successional and afforested spruce stands in Thuringia and the Alps. Global Change Biology, 12, 325-342.

Ussiri D.A.N. and Lal R., 2009. Long- term tillage effects on soil carbon storage and carbon dioxide emissions in continuous corn cropping system from alfisol in Ohio. Soil Till. Res., 104, 39-47.

van Asperen H., Warneke T., Sabbatini S., Höpker M., Nicolini G., Chiti T., Papale D., Böhm M., and Notholt J., 2017. Diel variation in isotopic composition of soil respiratory $\mathrm{CO}_{2}$ fluxes: The role of non-steady state conditions Agric. Forest Meteorol., 234-235, 95-105.

Vogel J.C., 1993. Variability of carbon isotope fractionation during photosynthesis. In: Stable Isotopes and Plant CarbonWater Relations (Eds B. Saugier, J.R. Ehleringer, A.E. Hall, and G.D. Farquhar), Academic Press, Elsevier Inc. San Diego-Boston-New York-London-Sydney-Tokyo-Toronto.

Wang M., Guan D.X., Han S.J., and Wu J.L., 2009. Comparison of Eddy Covariance and chamber-based methods for measuring $\mathrm{CO}_{2}$ flux in temperate mixed forest. Tree Physiol, 30, 149-163.

Xu M. and Qi Y., 2001. Soil-surface $\mathrm{CO}_{2}$ efflux and its spatial and temporal variations in a young ponderosa pine plantation in northern California. Global Change Biology, 7, 667-677.

Yakir D., 2003. The stable isotopic composition of atmospheric $\mathrm{CO}_{2}$. In: Treatise on Geochemistry (Eds Ralph F. Keeling), Elsevier, 347, 175-212. 